\title{
SULT1A1 wt Allele
}

National Cancer Institute

\section{Source}

National Cancer Institute. SULT1A1 wt Allele. NCI Thesaurus. Code C107442.

Human SULT 1A1 wild-type allele is located in the vicinity of 16p12.1 and is approximately $18 \mathrm{~kb}$ in length. This allele, which encodes sulfotransferase 1A1 protein, plays a role in the sulfate conjug ation of catecholamines, phenolic drugs and neurotransmitters. 